\title{
Synthesis, Characterization and Using of Nano - Nickel Metal Loaded on Egyption Kaolin for Reduction of p-Nitrophenol to p-Aminophenol
}

\author{
Amira M. Mahmoud ${ }^{(1)}$, Nadia A. Youssef ${ }^{(1)}$, Seham A. Shaban ${ }^{(2)}$ and \\ Mohamed M.Selim ${ }^{(3)}$
}

1-Faculty of Girls, Ain Shams University,

2- Egyptian Petroleum Research Institute(EPRI)

3-National Research Ceter.

\begin{abstract}
:
The p-aminophenol was prepared by reduction of p-nitrophenol over nano-sized nickel catalysts without support and with Egyptian kaolin as support. Hydrazine hydrate was used as hydrogen source in this reaction. Using solutions of nickel nitrate of appropriate concentrations to obtain catalysts with concentrations $2.5,5$ and $10 \%$ nickel loaded on Egyptian kaolin. The prepared Ni catalysts were characterised using X-ray and SEM before and after reduction of p-nitrophenol. The results showed that the degree of crystallinity of nano nickel particles was decreased after the reduction with agglomeration of nano nickel particles. The reduction of $\mathrm{p}$ nitrophenol was performed with different $\mathrm{Ni}$-concentrations from 2.5-10\%. The results showed that the increase of $\mathrm{Ni}$-content led to a decrease of the time taken for complete reduction of $\mathrm{p}$ nitrophenol and showed that $\mathrm{Ni}$ supported on kaolin was more active than the unsupported $\mathrm{Ni}$ catalyst for reduction of p-nitrophenol to p- aminophenol.
\end{abstract}

\section{Introduction.}

Metallic nanoparticles have been studied intensively within the last decade [Astruc,2007]. This interest originates from the fact that nanomaterials have enhanced catalytic properties. Examples for catalyzed reactions are C-C coupling reactions [Balanta et al.,2011;Gude, Narayanan,2011] or hydrogenations,[Berhault,2007;Piccolo,2008] which can be catalyzed by palladium nanoparticles. It was reported that $\mathrm{Pd}, \mathrm{Pt}, \mathrm{Rh}, \mathrm{Au}, \mathrm{Ru}$ and $\mathrm{Ni}$ nanoparticles exhibited higher catalytic activity than conventional supported metal catalysts in hydrogenation and oxidation reactions [Tian et al., 2007; Nolte,Kasper, 2008]

The catalytic activity and selectivity of metal nanoparticles are strongly dependent on their size and shape [Telkar et al. ,2003].

Kaolin is an earthy materials preponderantly containing the mineral china stoniest. It's a hydrous aluminum salt $\left(\mathrm{Al}_{2} \mathrm{O}_{3} \cdot 2 \mathrm{SiO}_{2} \cdot 2 \mathrm{H}_{2} \mathrm{O}\right)$ and features a wide range of business applications,

Corresponding author: ammaahmed@yahoo.com 
because of its distinctive physical, physiochemical and chemical properties [Asmatulu, 2002]. Distinctive geology, morphology, chemical and physical specifications of kaolin make its versatile staple applicable for several completely different applications [Mukherjee, 2013]. The p-aminophenol (PAP) is a commercially important intermediate for the manufacture of analgesic and antipyretic drugs [Lee and Chen ,1989]. Various methods have been reported to synthesize PAP, such as multi-step iron-acid reduction of p-nitrochlorobenzene or p-nitrophenol [Rode et al. ,2001], catalytic hydrogenation of nitrobenzene [Chaudhari et al., 2000], and an electrochemical synthesizing method [Yun and Cho, 1991].

Our present work describes the synthesis of phase pure nickel nanoparticles via simple chemical reduction route starting from nickel nitrate and hydrazine hydrate in methanol and study its catalytic activity with and without support (Egyption kaolin) to reduce p-nitrophenol to pamiophenol.

\section{2- Material and Methods.}

\subsection{Catalyst preparation.}

\section{1.a Preparation of nano-sized nickel over kaolin}

Kaolin supported nano-nickel catalysts were prepared by the direct reduction as follows. Firstly, $100 \mathrm{~g}$ of kaolin was washed gently with hot distilled water followed by soaking in $1 \mathrm{~L}$ of $1 \mathrm{M} \mathrm{NaCl}$ solution for $24 \mathrm{hr}$ at $30{ }^{\circ} \mathrm{C}$, to remove any undesirable components, decanted, washed and then dried in an air oven overnight at $100^{\circ} \mathrm{C}$. Secondly, nickel was loaded on kaolin by mean of wetness impregnation method at different contents; $2.5,5$ and $10 \mathrm{wt} \%$, and denoted as $2.5 \% \mathrm{Ni}$ / Kaolin, 5\% Ni / Kaolin and 10\% Ni / Kaolin, respectively.

\subsection{Apparatus}

\subsubsection{X-ray diffraction (XRD)}

$\mathrm{X}$-ray diffraction pattern were obtained using Druker D8 advance instrument whith $\mathrm{CuK} \alpha$ target with secondly monochromator $40 \mathrm{KV}, 40 \mathrm{~mA}$.

\subsubsection{Scanning electron microscope}

The speciemens were mounted on copper stubs with double-sides adhesive tape.The specimens were examined under JXA-840A Electron Probe Microanalyzer-JEOL-JAPAN.

\subsection{Reduction of nickel.}

All the prepared solids were reduced by addition of hydrazine hydrate and few drops of concentrated sodium hydroxide and heating the mixture at $80{ }^{\circ} \mathrm{C}$ until the colour of the mixture turned to black or grayish black, indicating complete reduction of nickel ions into nanonickel metals.

\subsection{Reduction of p-nitrophenol.}

$12.5 \mathrm{~g}$ of p-nitrophenol was dissolved in $50 \mathrm{ml}$ methanol and was added in doses each of them was $5 \mathrm{ml}$ to the reduced catalyst followed by $10 \mathrm{ml}$ hydrazine and few drops of $\mathrm{NaOH}$ 
solution.The mixture was heated until the colour is turned from yellow (p-nitrophenol) to colourless (p-aminophenol) which indicates complete conversion.

\section{Results and Discussion.}

\subsection{Characteristics of catalysts.}

\subsubsection{X-ray diffraction (XRD).}

$\mathrm{XRD}$ analysis is used to follow up the change in the crystallinity of Ni metal before and after the reaction.

Fig. $(1,2)$ show XRD for Ni unsupported before and after reduction of p-nitrophenol. They show that a change in the crystallinity of nickel occurs after the reduction of p-nitrophenol

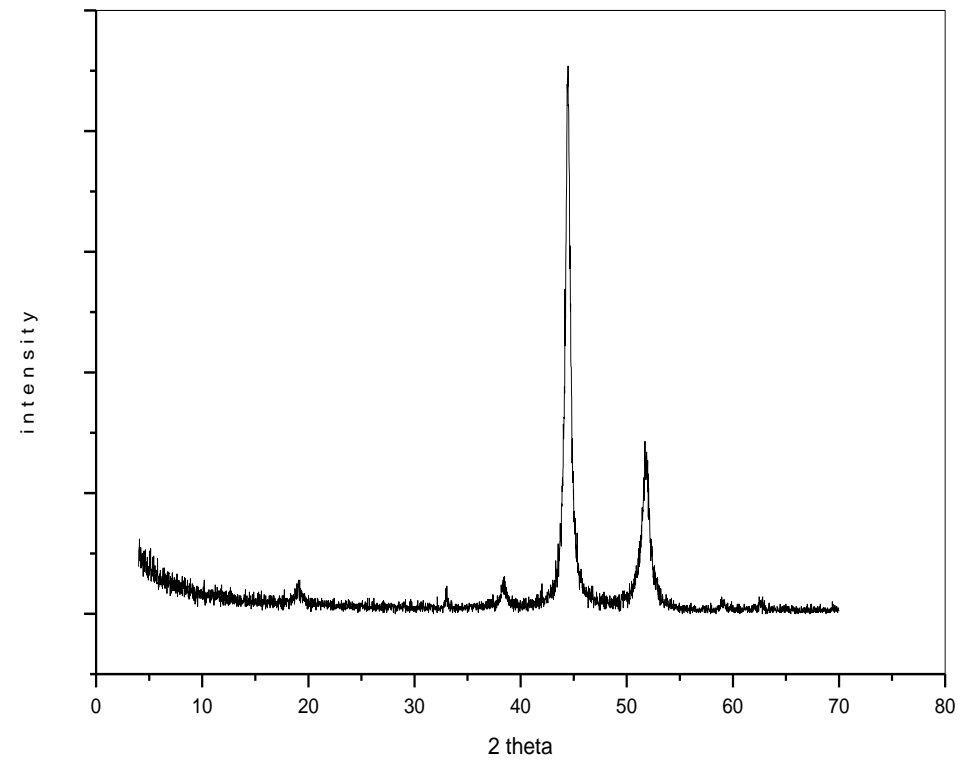

Fig.(1).XRD of un supported Ni before the reduction of PNP

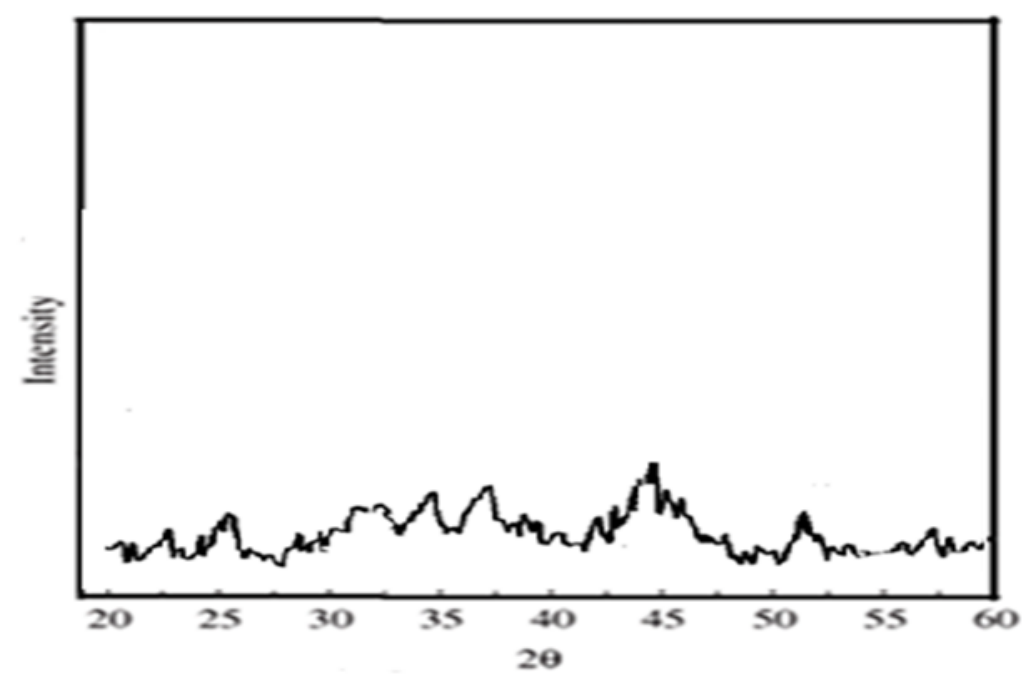

Fig.(2).XRD of un supported Ni after the reduction of PNP 
Fig. $(3,4)$ show XRD for $5 \% \mathrm{Ni} / \mathrm{Kaolin}$ before and after reduction of p-nitrophenol . They show small change in the crystallinity occurs after using in the reduction of p-nitrophenol

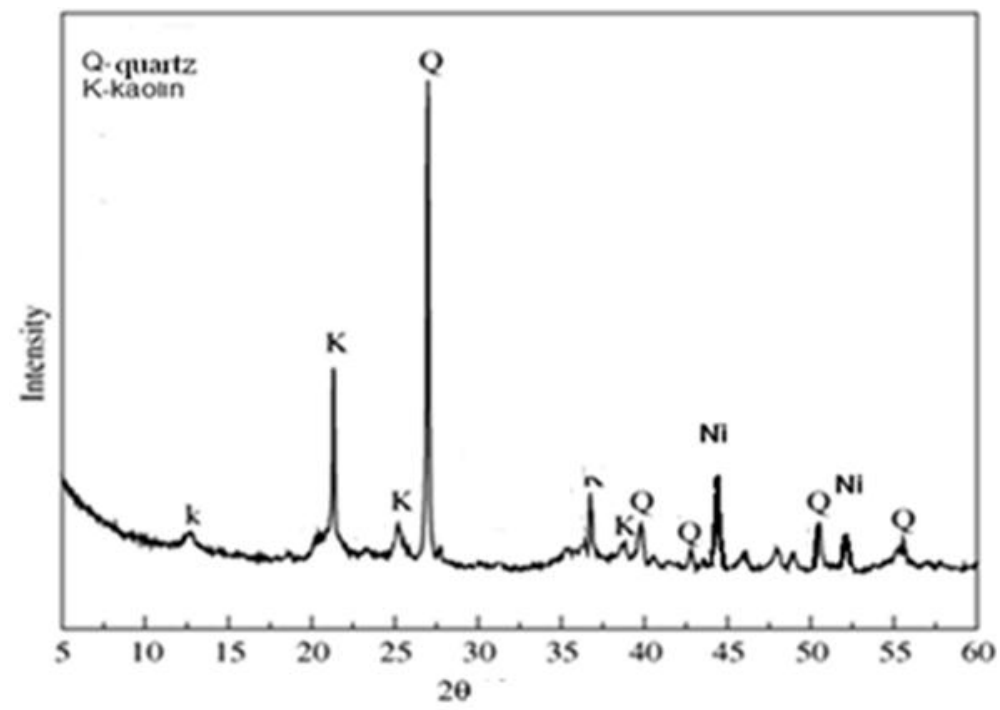

Fig.(3).XRD of Ni / kaolin befor the reduction of PNP

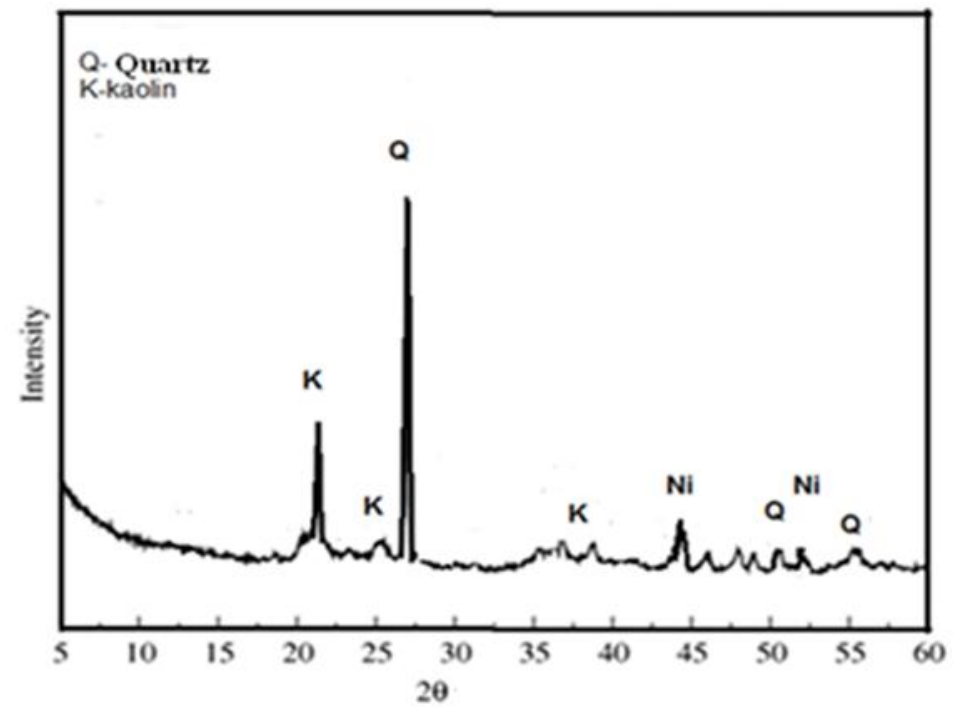

Fig.(4).XRD of Ni / kaolin after the reduction of PNP

\subsubsection{Scanning electron microscope (SEM)}

The reduced nano-metallic nickel is widely distributed as seen in Fig (5).

Fig.(6) shows that after reaction, the reduced nano nickel particles were agglomerated leading to less exposed surface for further reaction and consequently the reactivity of the catalyst is quickly decreased. 
Fig.(7) shows the kaolin containing nano nickel. From this figure it can be seen that the nano nickel is widely distributed on the surface of kaolin.

Fig.(8)illustrates that the presence of kaolin prevented to a large extent the agglomeration of nano nickel leaving it widely distributed on the kaolin surface and consequently the catalyst showed activity higher than the unsupported one.



Fig.(5).SEM for unsupported Ni before reduction of PNP.



$\mathbf{F i}$

Fig.(6).SEM for unsupported Ni after reduction of PNP

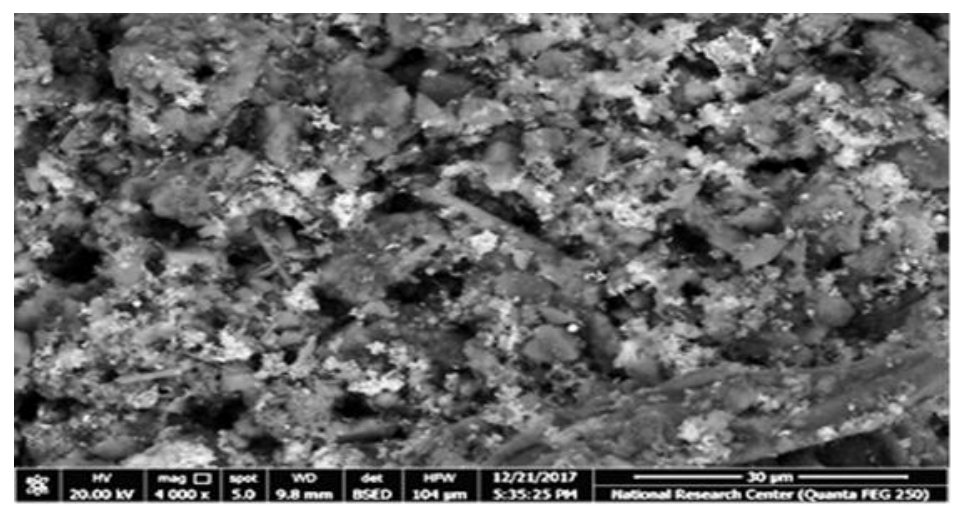

Fig.(7).SEM for Ni- loaded on kaolin before reduction of PNP 


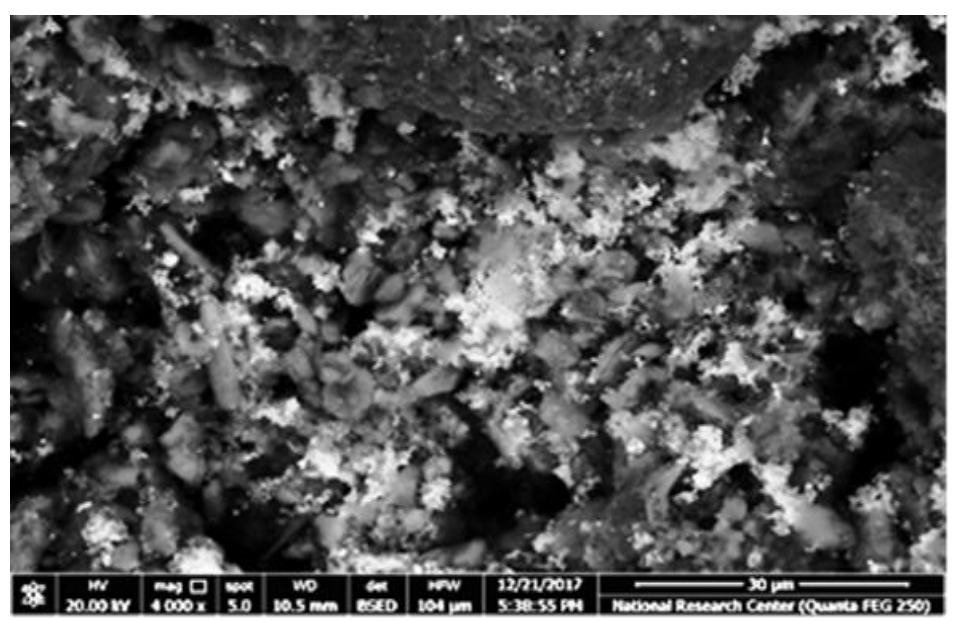

Fig.(8).SEM for Ni- loaded on kaolin after reduction of PNP

\subsection{Reduction of p-nitrophenol to p-aminophenol}

\subsubsection{Reduction of p-nitrophenol using different weights of unsupported $\mathrm{Ni}$.}

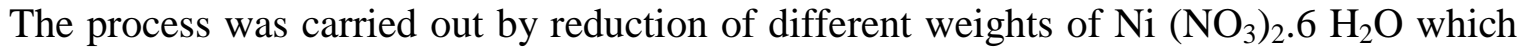
equivalent to $2.5,5$ and $10 \% \mathrm{Ni}$ in case of unsupported catalysts. A series of reduction of different doses of p-nitrophenol with conc. (1.7 $\mathrm{M}$ in $50 \mathrm{ml}$ ) each addition is $5 \mathrm{ml}$ solution was performed. The results are represented in Fig.(9).

From Fig. ( 9 ) it can be shown that the increase of the weight of nickel catalyst increases the possibility for more reduction of p-nitrophenol and decrease the time taken for reduction of $\mathrm{p}$ nitrophenol solution. 




Fig.(9). The relation between the no. of additions of p-nitrophenol and time taken for reduction of PNP by different weights of unsupported Ni.

\subsubsection{Reduction of p-nitrophenol by different weights of catalyst containning $2.5 \% \mathrm{Ni}$ - loaded on kaolin.}

In this series of experiments the reduction of p-nitrophenol was performed on different weights of catalyst containing $2.5 \% \mathrm{Ni} /$ kaolin.

Fig.(10) shows that the increae of catalyst weight decreases the time of complete reduction of p-nitrophenol to p-aminophenol.

Fig.(11) shows that the optimum catalyst weight was chosen at $1 \mathrm{~g}$ of $2.5 \% \mathrm{Ni} / \mathrm{kaolin}$ and the increase of weight after that to 1.25 and $1.5 \mathrm{gm}$. has nearly the same time for reduction of PNP. 


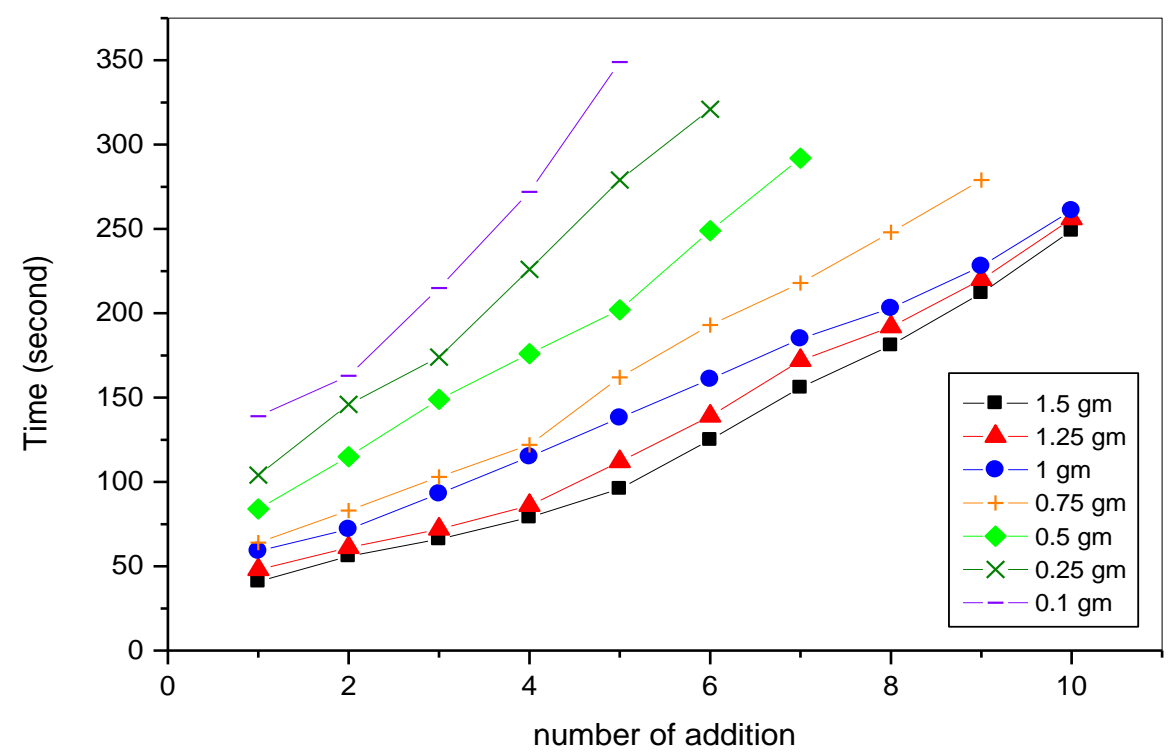

Fig.(10). The relation between the no. of additions of p-nitrophenol and time taken for reduction of PNP by different weights of $2.5 \% \mathrm{Ni} /$ kaolin

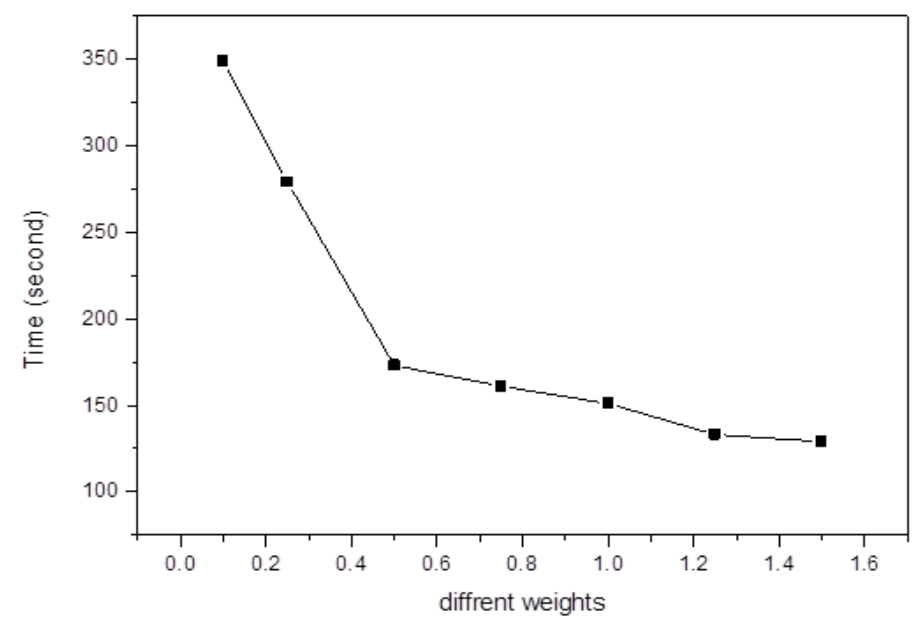

Fig.(11). Effect of catalyst weights of $2.5 \% \mathrm{Ni} /$ kaolin on the reduction of PNP to PAP

\subsubsection{Reduction of p-nitrophenol by different weights of catalyst containning $5 \% \mathrm{Ni}$ - loaded on kaolin}

In this series of experiments the reduction of p-nitrophenol was performed on different weights of catalysts containing $5 \% \mathrm{Ni} /$ kaolin.

The results of this series are illustrated in Fig.( 12, 13 ), From the figures it is shown that the increae of catalyst weight lead to increases the complete conversion of p-nitrophenol to paminophenol and $1 \mathrm{~g}$ of $5 \% \mathrm{Ni} / \mathrm{Kaolin}$ is the optimum weight and increasing of weight after that to 1.25 and $1.5 \mathrm{~g}$ has nearly the same time for reduction of PNP. 


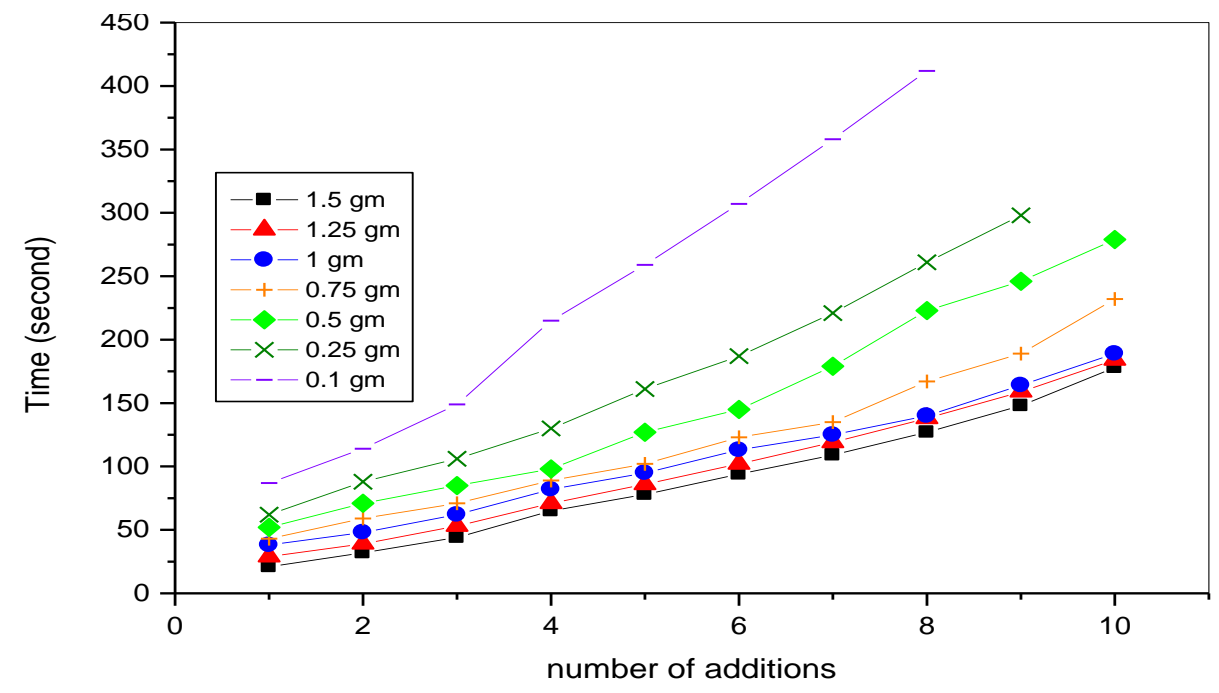

Fig.(12). The relation between the no. of additions of p-nitrophenol and time taken for reduction of PNP by different weights of $5 \% \mathrm{Ni} /$ kaolin

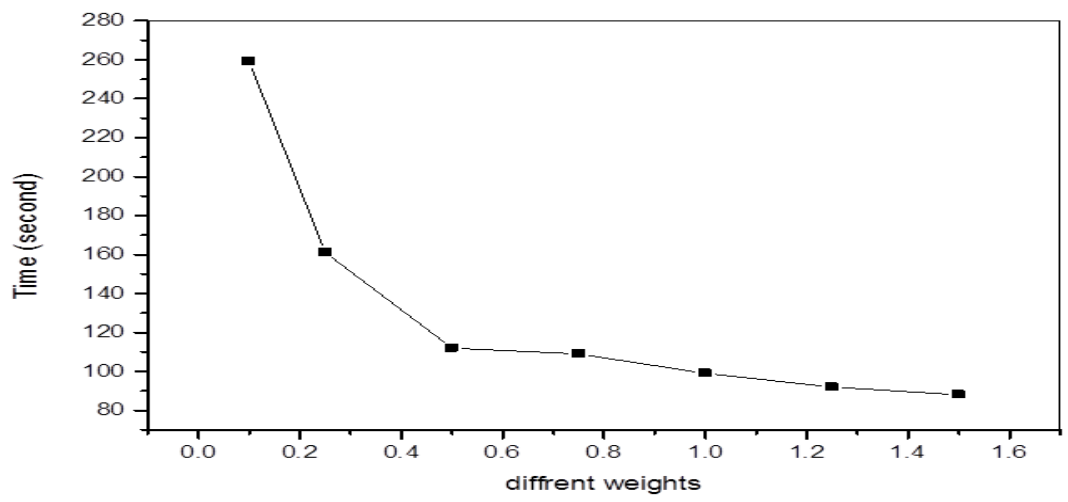

Fig.(13). Effect of catalyst weights of 5\% Ni / kaolin on the reduction of PNP to PAP

\subsubsection{Reduction of p-nitrophenol by different weights of catalyst containning $10 \% \mathrm{Ni}$ - loaded on kaolin}

In this series of experiments the reduction of p-nitrophenol was performed on different weights of catalysts containing $10 \% \mathrm{Ni} /$ kaolin.

The results of this series are illustrated in Fig.(14 ). From these it can be seen that the increae of catalyst weight increases the reduction rate of p-nitrophenol into p-aminophenol.

From Fig.(15) it is shown that $1 \mathrm{gm}$ of $10 \% \mathrm{Ni} /$ kaolin is the optimum weight and increasing of weight after that to 1.25 and $1.5 \mathrm{~g}$ has nearly the same time for reduction of PNP 


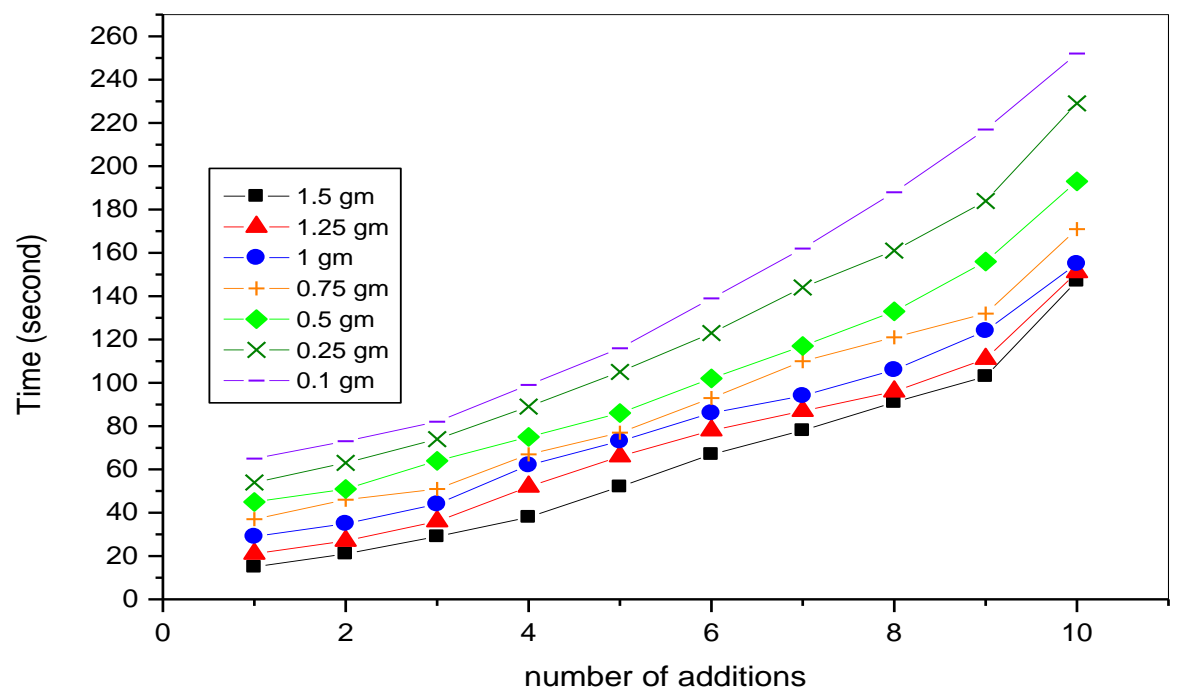

Fig.(14). The relation between the no. of additions of p-nitrophenol and time taken for reduction of PNP by different weights of $10 \% \mathrm{Ni} /$ kaolin



Fig.(15). Effect of catalyst weights of $10 \% \mathrm{Ni} /$ kaolin on the reduction of PNP to PAP

\section{Conclusion.}

The unsupported nickel and nickel loaded on Egyption kaolin can be used for reduction of p-nitrophenol to p-aminophenol.

In case of nickel loaded on Egyption kaolin it was shown that the activity increases with increase the weight of the catalyst that is to say $(10 \%>5 \%>2.5 \%)$ Ni-loaded on kaolin > unsupported nickel.

For 2.5, 5, 10\% Ni loaded on Egyptian kaolin $1 \mathrm{gm}$ is the optimum weight and increasing of weight after that to 1.25 and $1.5 \mathrm{~g}$ has nearly the same time for reduction of PNP. 


\section{Refrence.}

Asmatulu .R, "Removal of discoloring contaminants of an east Gergai Kaolin and its dewatering

" Turkish J. Eng. Env. Sci. vol. 26, 447-453 (2002) .

Astruc .D, Nanoparticles and Catalysis, Wiley-VCH Verlag GmbH \& Co. KGaA, Weinheim, (2007).

Balanta. A, Godard .C, Claver .C, Pd nanoparticles for C-C coupling reactions, Chem. Soc. Rev., 40, 4973 (2011).

Berhault. G , Bisson .L, Thomazeau. C, Verdon .C, Preparation of nanostructured Pd particles using a seeding synthesis approach -Application to the selective hydrogenation of buta-1,3diene, Appl. Catal., A, 327, 32 (2007).

Chaudhari .R.V, Divekar .S.S, Vaidya .M.J, Rode. C.V, US Patent to Council of Scientific \& Industrial Research (New Delhi, IN) 6,028,227 (2000).

Gude .K, Narayanan .R, Colloidal Supported Metal Nanoparticles (CSMNs) as Effective Nanocatalysts for Liquid-Phase Suzuki Cross-Coupling Reactions, J. Phys. Chem. C, 115, 12716 (2011).

Lee .L.T, Chen .M.H, Yao .C.N, US Patent to Industrial Technology Research Institute (TW) 4,885,389 (1989).

Liu .Y.C, Chen .Y.W, Hydrogenation of p-Chloronitrobenzene on Lanthanum-Promoted NiB Nanometal Catalysts, Ind. Eng. Chem.Res.45, 2973(2006).

Mukherjee. S, "Application in Industry Engineering and Environment". The Science of Clays Springer. India. (2013).

Nolte .P, Stierle .A, Kasper .N, Shape Changes of Supported Rh Nanoparticles During Oxidation and Reduction Cycles, science 321, 1654 (2008).

Piccolo .L, Valcarcel .A, Bausach .M, Thomazeau .C, Berhault. G, Tuning the shape of nanoparticles to control their catalytic properties: selective hydrogenation of 1,3-butadiene on $\mathrm{Pd} / \mathrm{Al}_{2} \mathrm{O}_{3}$, Phys. Chem. Chem. Phys., 10, 5504 (2008).

Refaei .A, Abdelrahman .MK, Kandil .F, “Improvement the Quality of Egyptian Kaolin for Industrial Applications "Int J Adv Techno 8-1 (2017).

Rode .C.V, Vaidya .M.J, Jaganathan .R, Chaudhari .R.V, Chem. Eng. Sci. 56, 1299 (2001).

Telkar .M.M, Rodea .C.V, Chaudhari. R.V, Joshi .SSShape-controlled preparation and catalytic activity of metal nanoparticles for hydrogenation of 2-butyne-1,4-diol and styrene oxide .Appl.Catal.A: Gen 273, 11(2004).

Tian .N, Zhou .Z.Y, Sun .S.G, , Synthesis of tetrahexahedral platinum nano crystals with highindex facets and high electro-oxidation activity, Science 316, 732 (2007).

Vaidya .M.J, Kulkarni .S.M, Chaudhari .R.V, Synthesis of p-Aminophenol by Catalytic Hydrogenation of p-Nitrophenol, Org. Process Res. Dev. 7, 202(2003).

Yun .K.S, Cho .B.W, US Patent to Korea Institute of Science and Technology (KR). 5,066,369 (1991) 


\section{الملخص باللغة العربية}

\section{تحضيرو توصيف فلز النيكل النانوي المحمل علي الكاوليين المصري و إستخدامه في إختزال

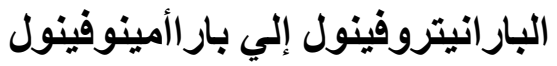

أميره ماهر محمود علي' ، نادية عبد الحكيم يوسفَ ، محمد محمد عبد المنعم سليمّ ، سهام علي شعبان؛

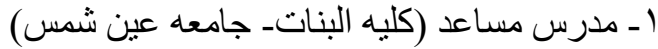

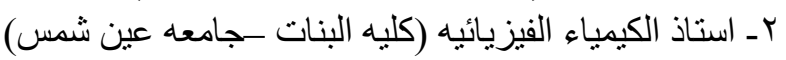

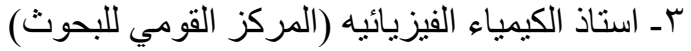

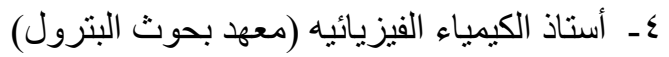

\section{الملخص العربي}

يستخدم البار أمينوفينول في العديد من الصناعات الدوائيه لانتاج المسكنات و مضادات الالتهاب مثل فئل

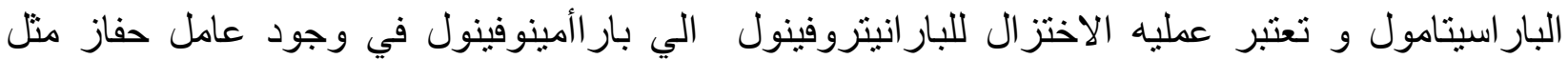
البلاتين او البلاديوم او النيكل اقل الطرق تلويثا للبيئه فهي الخيار الانظف و الانئني لانتاج البار المينوالينوفينول.

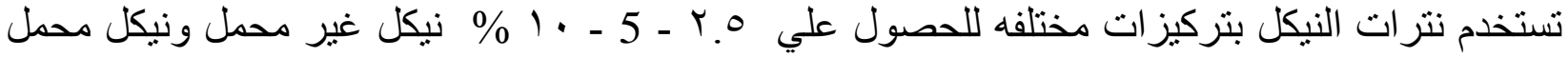



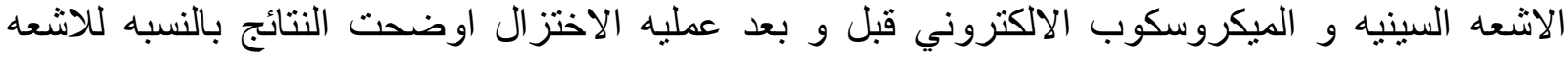

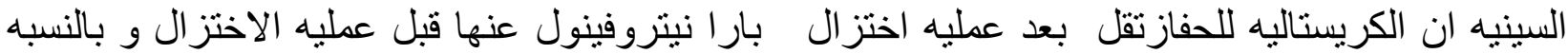

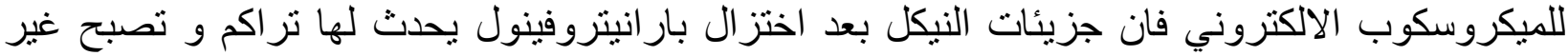
قادره علي الدخول في تفاعل اخر مما يقلل الكفاءه الحفزيه لها.

عند استخدام اوزان مختلفه للنيكل غير المحمل وجد انه بزياده الوزن تزداد الكفاءه الحفزيه و يقل الزمن المستهلك لاختز ال بار انيتروفينول الي بار أمينوفينول.

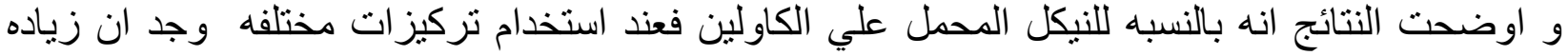





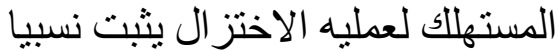

و من النتائج السابقه فان الكفاءه الحفزيه للنيكل المحمل علي كاوليين اكبر من الكفاءه الحفزيه للنيكل الغير محمل.

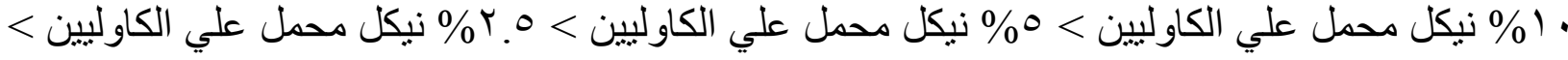



